\title{
Giant Cell Tumour of Spine - A Rare Case
}

\author{
Anusha Madhuri' ${ }^{1}$ Zaheda Kausar², Anunayi J, ${ }^{3}$ \\ ${ }^{1}$ Department of Pathology, Osmania Medical College, Koti, Hyderabad, Telangana, India. \\ ${ }^{2}$ Department of Pathology, Osmania Medical College, Koti, Hyderabad, Telangana, India. \\ ${ }^{3}$ Department of Pathology, Osmania Medical College, Koti, Hyderabad, Telangana, India.
}

\section{INTRODUCTION}

Spine is an unusual site for giant cell tumour (GCT). The largest of the series was published by Dahlin in the year 1977. Giant cell tumour of the spine is most aggressive benign tumour of the spine with unpredictable outcome. We report a case of 29 years old male patient with giant cell tumour of spine, clinically diagnosed as spinal tuberculosis. Patient presented with cord compression and neurological deficits in upper limb. Patient presented with clinical as well as radiological instability.

Giant cell tumour (GCT) of bone is a rare neoplasm that accounts for approximately $5 \%$ of all primary bone tumours in adults. ${ }^{1}$ GCT most frequently occurs at the end of long bones. ${ }^{2}$ Giant cell tumour also occurs in the mobile spine, but this location accounts for only $2-4 \%$ of cases. ${ }^{3}$ In all locations, the neoplasm occurs most commonly between the ages of 20 - 45 years and it affects males and females with equal frequency. ${ }^{1}$ It is the most aggressive of the benign primary tumours of the spine, ${ }^{4}$ with a high predilection for recurrence. Due to the unusual site and nonspecific symptoms Giant cell tumour of spine is a challenge to the treating surgeons. We report a case of giant cell tumour cervical vertebrae where in patient presented with signs and symptoms of cord compression and was provisionally diagnosed as tuberculosis spine.

\section{PRESENTATION OF CASE}

A 29-year-old male presented with pain in the neck and numbness in left upper limb since 1 month. On clinical examination, there was decrease in sensation by about 50 $\%$ in C5 - C6 dermatome in left upper limb. Magnetic Resonance Imaging (MRI) showed pathological destruction with compression and collapse of C6 vertebral body. Spinal canal stenosis with cord compression at C6 level was noted. C6 corpectomy with C5 - C6 inter-body fusion with cage graft and fixation was performed and the specimen was sent in formalin for histopathological examination to the Department of Pathology.
Corresponding Author: Dr. Zaheda Kausar, Flat No. 203, York Enclave, 6/66/6, Khizra Colony, Hyderabad-500089, Telangana, India. E-mail: zahedar11@gmail.com

DOI: $10.14260 /$ jemds/2020/639

How to Cite This Article: Madhuri A, Kausar Z, Anunayi J. Giant cell tumour of spine - a rare case. J Evolution Med Dent Sci 2020;9(39):2921-2923, DOI: $10.14260 / \mathrm{jemds} / 2020 / 639$

Submission 29-08-2019,

Peer Review 19-05-2020,

Acceptance 27-05-2020,

Published 28-09-2020.

Copyright (C) 2020 JEMDS. This is an open access article distributed under Creative Commons Attribution License [Attribution 4.0 International (CC BY 4.0)] 

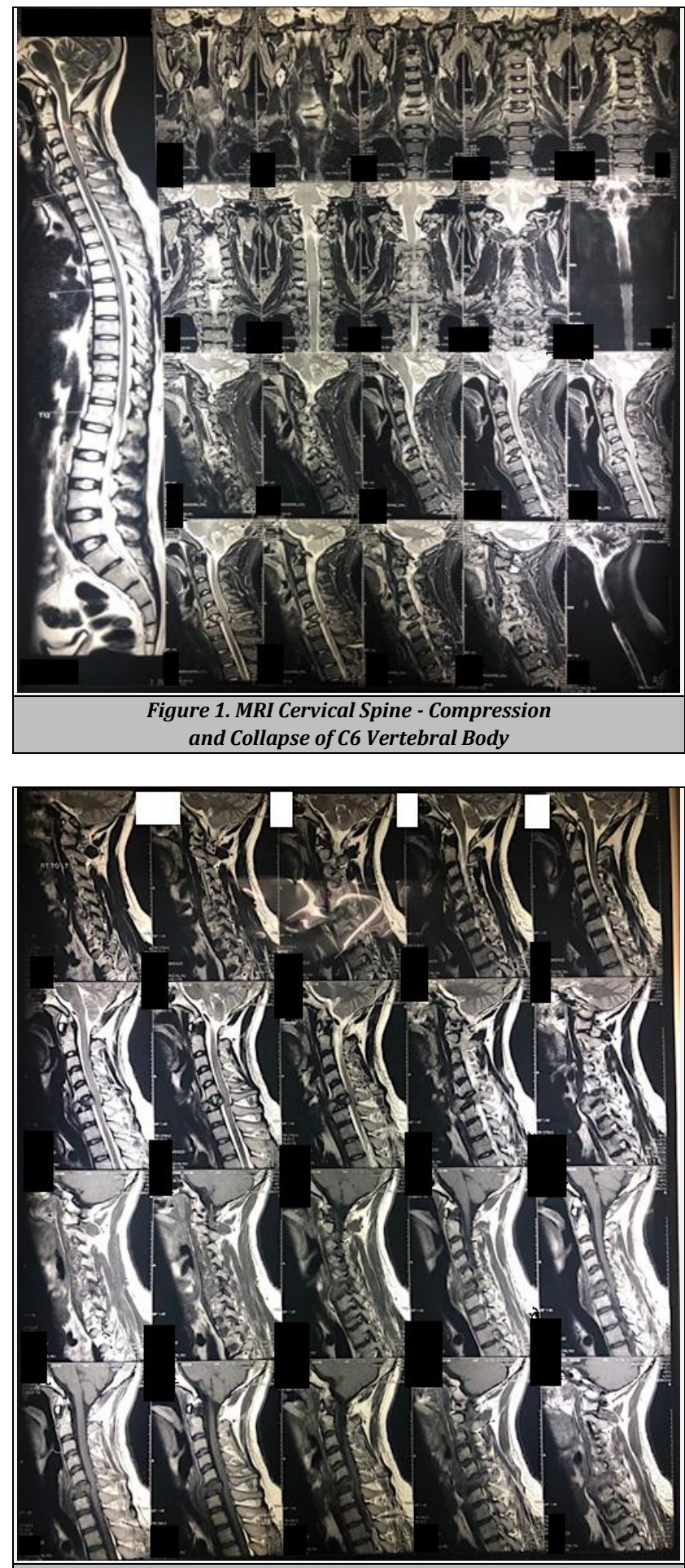

Figure 2. Spinal Canal Stenosis with Mild Cord Compression

\section{Gross Examination}

Multiple gray brown soft tissue bits all together measuring 3 cc.

\section{Microscopy}

Multiple sections studied from C6 cervical mass shows fibrohyaline cartilage, nucleus pulposus and tumour tissue. Tumour is composed of stromal cells and numerous osteoclast type of giant cells and areas of haemorrhage. Diagnosed as giant cell tumour-cervical spine (C6)
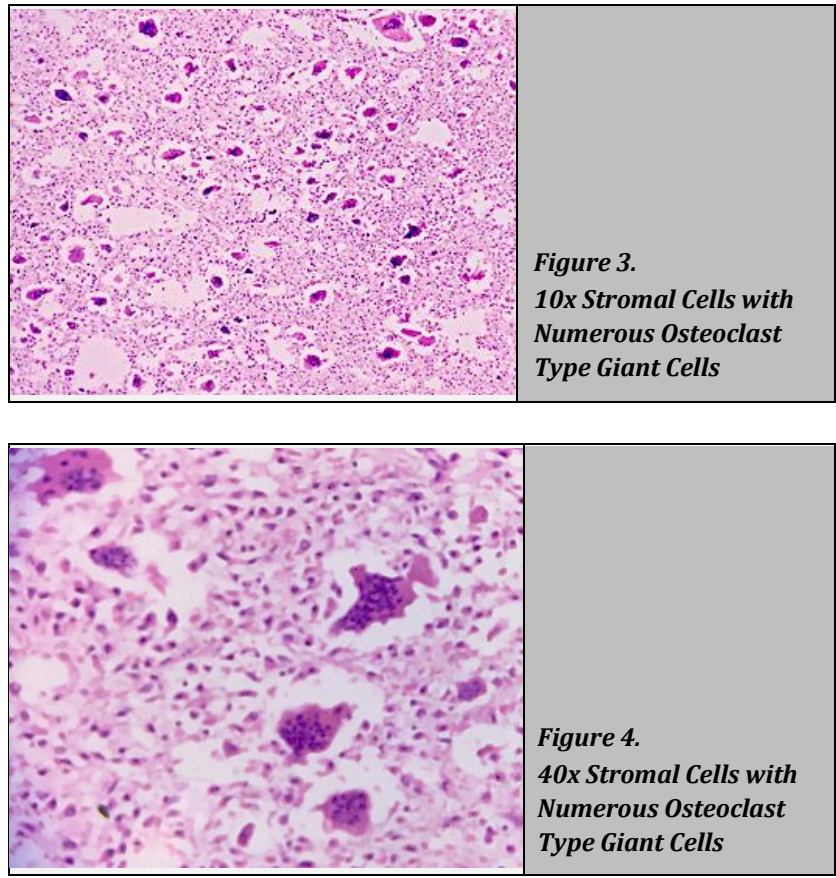

\section{DISCUSSION}

Thoracic and lumbar vertebrae are a common site of spinal tuberculosis. ${ }^{5}$ On the other hand, the epiphyseal ends of long bones is classical location for GCT. In developing countries such as India, when it occurs in vertebrae, it warrants an alternate diagnosis. ${ }^{6}$ The patient in this case report presented with signs of radiculopathy. Based on the clinical picture and considering the young age of the patient, clinically a provisional diagnosis of spinal tuberculosis was made. The radiographic features of GCT at sites other than the long bones are nonspecific. ${ }^{7}$ Spinal canal Stenosis and mild cord compression were seen in our case. Review of literature reveals that GCT of the spine almost always begins in the vertebral body leading to vertebral collapse. ${ }^{6}$ Histologically, GCT is composed of multinucleated osteoclastic giant cells and spindle shaped neoplastic mononuclear stromal cells. Other tumours with giant cells are aneurysmal bone cyst, chondroblastoma, benign fibrous histiocytoma, chondromyxoid fibroma, brown tumour of hyperparathyroidism, and giant cell-rich osteosarcoma. ${ }^{8}$ The distinctive spatial distribution of giant cells along with radiological correlation differentiates GCT from others. ${ }^{8}$ The true histogenesis of these tumours remains unclear, however, evidence favours a mesenchymal origin. Grading system was developed by Campanacci. The Grade I tumour presents well-defined margins and a thin "halo" of mature bone. The Grade II tumour is well delimited, but does not present a sclerotic halo. The Grade III lesion has ill-defined borders, suggesting aggressiveness.

The most significant factor determining the risk of recurrence is the type of initial surgical intervention ${ }^{8}$ and Grade III lesions, as the tumour breach the normal anatomic boundaries and extend into the soft tissue. Long-term surveillance is recommended as recurrence is common. The most common site for metastasis is lungs. ${ }^{6}$

The treatment of spinal GCT is not well defined as it is for the long bones. ${ }^{1}$ En bloc excision should be pursued as the 
surgical procedure of choice for management of spinal GCT. (1) When en bloc excision is prohibited due to the high risk of post-operative morbidity, pre-operative embolization followed by intralesional resection should be the procedure of choice. ${ }^{1}$ Radiotherapy is an issue under debate as post radiation sarcoma is a common occurrence after the treatment.

\section{CONCLUSIONS}

A differential diagnosis of GCT should be kept in mind while evaluating a young patient presenting with radiculopathy and spinal lesion. Tissue biopsy remains the "gold standard" for diagnosis of spinal GCT. An accurate diagnosis with precise treatment is required, as this tumour has been known to implant into the surrounding tissues and metastasise.

Financial or Other Competing Interests: None.

\section{REFERENCES}

[1] Martin C, McCarthy EF. Giant cell tumour of the sacrum and spine: series of 23 cases and a review of the literature. Iowa Orthop J 2010;30:69-75.

[2] Turcotte RE. Giant cell tumour of bone. Orthop Clin North Am 2006;37(1):35-51.

[3] McDonald DJ, Sim FH, McLeod RA, et al. Giant-cell tumour of bone. J Bone Joint Surg Am 1986;68(2):23542.

[4] Sertbaş I, Karatay M, Hacisalihoğlu UP. Cervical spine giant cell bone tumour: a case report. World J Surg Oncol 2019;17(1):82.

[5] Dass B, Puet TA, Watanakunakorn C. Tuberculosis of the spine (Pott's disease) presenting as compression fractures. Spinal Cord 2002;40(11):604-8.

[6] Jha K, Pant I, Singh G, et al. Giant cell tumour of the spine masquerading as spinal tuberculosis: an uncommon entity. Int J Health Allied Sci 2016;5(4):284-7.

[7] Purohit S, Pardiwala DN. Imaging of giant cell tumour of bone. Indian J Orthop 2007;41(2):91-6.

[8] Goldblum J, Lamps L, McKenney J, et al. Bone and joints. Rosai and Ackerman's surgical pathology. 11 th edn. Elsevier 2017. 